\title{
STUDI KASUS GAMBARAN COPING STRES PADA MAHASISWI PEKERJA SEKS KOMERSIAL
}

\author{
Salsabila Nurul Hidayati ${ }^{1}$ \\ Dr. Gantina Komalasari, Psi ${ }^{2}$ \\ Dra. Indira Chanum Chalik, M.Psi ${ }^{3}$
}

\begin{abstract}
Abstrak
Tujuan dari penelitian ini adalah untuk mengungkap tentang strategi coping stres yang digunakan oleh mahasiswi yang menyambi sebagai pekerja seks komersial (PSK). Metode yang digunakan adalah studi kasus dalam pendekatan kualitatif. Penelitian ini dilaksanakan di tempat kos dan kampus daerah Jakarta, dengan dua responden yaitu mahasiswi angakatan 2010 dengan nama samaran Rani dan Mawar. Pengumpulan data dilakukan melalui wawancara, observasi dan dokumentasi. Wawancara yang dilakukan adalah wawancara terstruktur terhadap subjek atau kasus, orang tua, teman kos dan teman kampus dengan mengacu pada teori coping stres dari Lazarus dan Folkman. Data hasil penelitian dianalisis secara deskriptif kualitatif melalui studi kasus, adapun penyajian data menggunakan narasi. Pemeriksaan keabsahan data dilakukan dengan triangulasi sumber data. Hasil penelitian keseluruhan menunjukan adanya coping stres yang dilakukan oleh Rani dan Mawar. Untuk strategi coping pada subjek Rani menggunakan problem focused coping yaitu dengan menceritakan masalah yang dihadapinya kepada teman dekatnya dan emotion focused coping yaitu dengan cara merokok untuk mengatasi stresnya, sedangkan subjek Mawar lebih cenderung menggunakan emotion focused coping saja yaitu dengan memendam kecemasannya dan berpura-pura tidak terjadi apa-apa, menarik diri dari lingkungan masyarakat selain itu subyek juga sering meminum obat tidur agar bisa melupakan masalahnya.
\end{abstract}

Kata kunci: coping stres, gambaran coping stres, mahasiswi pekerja seks komersial

\section{Pendahuluan}

Menurut Hull, prostitusi di Indonesia sudah ada semenjak masa kerajaan-kerajaan Jawa, dimana perdagangan perempuan pada saat itu merupakan pelengkap dari sistem pemerintahan feodal. $\mathrm{Pa}$ da masa itu konsep kekuasaan raja digambarkan sebagai kekuasaan yang sifatnya agung dan mulia. Kekuasaan ini tercermin dari banyaknya selir yang mereka miliki. Keadaan inilah yang membentuk landasan bagi perkembangan industri seks yang ada sekarang.

Fenomena yang dianggap sebagai penyakit masyarakat ini tetap berkembang dengan pesat, bahkan telah mewabah dalam dunia pendidikan. Pelaku pelacuran dalam dunia kampus dari kalangan mahasiswi ini lebih kita kenal dengan sebutan ayam kampus. Akan tetapi dibalik itu semua tersimpan kenyataan pahit, Koentjoro mengemukakan bahwa wanita pekerja seks komersial selalu mengalami konflik dalam dirinya, baik konflik kepentingan an-

\footnotetext{
Mahasiswa Jurusan Bimbingan dan Konseling FIP UNJ, annsabila@yahoo.co.id

2 Dosen Bimbingan dan Konseling FIP UNJ, gantina_komalasari@yahoo.com

3 Dosen Bimbingan dan Konseling FIP UNJ,
} 
tara rasa membutuhkan uang dan perasaan berdosa, atau juga karena adanya perasaan tidak aman akan statusnya sebagai pekerja seks komersial dalam masyarakat. Berdasarkan hasil penelitian yang dilakukan oleh Weisberg, menemukan bahwa hampir semua pelacur merasakan ketidakcukupan, ketidakpastian, dimusuhi dan mempunyai kesulitan dalam membentuk rapport dan cenderung menarik diri dari masyarakat. Sehingga dapat disimpulkan bahwa mahasiswi pekerja seks komersial dapat mengalami stres dan hal tersebut dapat berdampak negatif apabila tidak segera ditangani sehingga diperlukan coping stress.

Rumusan masalah "Strategi coping stres apa yang digunakan mahasiswi yang menjadi PSK dalam menghadapi stres?". Tujuan penelitian ini adalah untuk mengetahui strategi coping yang digunakan pada mahasiswi yang berprofesi menjadi PSK untuk mengatasi stresnya ketika mereka berada di dunia malam dan juga ketika mereka berinteraksi dengan lingkungan tempat tinggal serta lingkungan kampus di kehidupan sehari-hari.

\section{Kajian Teori}

Coping merupakan sebuah usaha untuk mengatasi keadaan kurang menyenangkan yang dirasakan dengan menggunakan cara tertentu. Adapun tahapan dalam proses coping itu sendiri ada tiga tahapan, pertama yaitu tahap peringatan, kedua yaitu tahap menghadapi, dimana individu mulai menerapkan coping yang dipilihnya dan yang ketiga yaitu tahap evaluasi setelah menghadapi keadaan. Coping tidak selalu bisa mengubah keadaan, dan coping yang efektif adalah coping yang dapat menenrima keadaan yang menekan tanpa menyakiti dirinya sendiri.

Jenis Coping dibagi menjadi 2 yaitu problem focused coping dan emotion focused coping. Problem focused coping adalah usaha coping yang dilakukan dengan mengurangi atau mengubah situasi yang mejadi sumber stressor bagi individu tersebut. Coping ini diarahkan untuk mendifinisikan masalah, menghasilkan solusi alternatif, bobot alternatif dan manfaatnya dan kemudian bertindak.

Indikator dari problem focused coping menurut Lazarus dan Folkman yaitu:
1. Seek social support, ditandai dengan pencarian informasi yang berkaitan dengan stressor, memperoleh bimbingan dari para ahli atau profesional, berbicara dengan teman, orangtua ataupun orang lain dan meminta bantuan yang lebih spesifik terhadap masalah.

2. Planful problem solving. ditandai dengan adanya usaha untuk membuat rencana alternatif, membuat pilihan secara objektif dan mempertimbangkan beberapa kemungkinan sebelum bertindak

3. Confrontative coping, ditandai dengan adanya usaha mengubah aktifitas dan menciptakan suasana baru, membangun hubungan sosial alternatif, bertindak langsung, adanya rasa tantangan dan memotivasi diri sendiri.

Emotion focused copying merupakan usaha coping berupa menggunakan emosi atau perasaan yang ada pada dirinya dalam menghadapi masalah. Indikator emotion focused coping yaitu:

1. Self control, ditandai dengan adanya usaha untuk menyembunyikan perasaan, melakukan kegiatan berdasarkan perasaan, mencoba untuk tidak diganggu oleh perasaan yang bertentangan dan adanya sikap berpura-pura.

2. Accept responsibility, ditandai dengan adanya pemahaman peran pribadi dalam situasi stres, memperkirakan hal yang terburuk, menerima situasi yang terjadi dan mencoba belajar dari kesalahan.

3. Distancing, indikator ini ditandai dengan pengambilan jarak dari situasi stres.

4. Positive Reappraisal, indikator ini ditandai dengan adanya usaha untuk melihat situasi stres dari sisi yang berbeda dan melihat sisi positif dari situasi stres

5. Escape/avoidance, indikator ini ditandai de-ngan penolakan untuk menerima perubahan dengan cara menghindari situasi stres, adanya usaha untuk meluapkan emosi, menangis, merokok dan menarik diri.

Mahasiswa menurut Santrock adalah sekumpulan individu yang secara resmi terdaftar untuk mengikuti kegiatan belajar di perguruan tinggi. Mahasiswa didefinisikan sebagai individu yang telah menyelesaikan Sekolah Menengah Atas dan memasuki per- 
guruan tinggi. Sedangkan definisi mahasiswa dalam peraturan pemerintah RI No.30 tahun 1990 adalah peserta didik yang terdaftar dan belajar di perguruan tinggi tertentu. Usia mahasiswa pada masa dewasa awal berada pada rentangan 18-22 tahun. Definisi tersebut berlaku untuk mahasiswa di jenjang S1, sedangkan bagi mahasiswa S2 dan S3 usia mereka dapat melampaui 22 tahun.

Sedangkan definisi dari pelacuran adalah sebuah usaha memperjual-belikan kegiatan seks di luar nikah dengan imbalan materi, pelacur diartikan sebagai perempuan atau laki-laki yang melakukan kegiatan seks di luar nikah dengan imbalan materi.

Mahasiswi yang menjadi pekerja seks komersial memiliki ciri memakai perhiasan dan dandanan yang agak mencolok atau menarik perhatian, sering keluar di malam hari dan memiliki teman pria yang banyak, selain itu mereka juga cenderung tertutup ketika membicarakan hal-hal yang berkaitan dengan seks jika bukan dengan teman dekatnya.

\section{Metode Penelitian}

Penelitian ini dilakukan kepada dua mahasiswi yang bekerja sebagai pekerja seks komsersial di daerah Jakarta. Penelitian dilaksanakan di lingkungan tempat tinggal, tempat kuliah dan tempat kerja subyek pada bulan November 2013 hingga April 2014. Metode yang digunakan dalam penelitian ini adalah pendekatan kualitatif dengan metode studi kasus.

Teknik pengumpulan data dilakukan dengan cara:

1. Wawancara (indepth interview). Pada penelitian ini wawancara pada responden dilakukan sebanyak 5 kali dengan durasi 30-60 menit. Selain itu peneliti juga melakukan wawancara pada pihak-pihak yang terkait (teman kost subyek, teman kampus subyek dan orangtua) masing-masing responden untuk memperoleh informasi yang mendalam dan akurat dari pihak lain, selain responden dan juga menguji keabsahan untuk uji keabsahan data.

2. Observasi. Pada penelitian ini menggunakan observasi terus terang atau bersamar, peneliti dalam melakukan pengumpulan data menyatakan terus terang kepada sumber data, bahwa ia sedang melakukan penelitian. Jadi mereka yang diteliti mengetahui sejak awal sampai akhir aktivitas peneliti. Tetapi dalam suatu saat, peneliti juga tidak terus terang atau tersamar dalam observasi, dalam hal ini untuk menghindari jika suatu data yang dicari merupakan data yang masih dirahasiakan. Kemungkinan kalau dilakukan dengan terus terang, maka peneliti tidak akan diijinkan untuk melakukan observasi. Observasi yang akan dilakukan yaitu observasi mengenai keseharian subyek saat berada di lingkungan tempat tinggalnya (kos), lingkungan di tempat kerja-nya (cafel diskotik) dan saat berada di lingkungan kampus.

\section{Dokumentasi}

Tabel 1. Pedoman Studi Dokumentasi

\begin{tabular}{|c|c|c|}
\hline No & Data dokumentasi & Keterangan \\
\hline 1. & Lingkungan tempat kerja & Tempat karaoke/diskotik \\
\hline 2. & Lingkungan tempat tinggal & Tempat Kos \\
\hline 3. & Lingkungan tempat kuliah & Kampus \\
\hline
\end{tabular}

Teknik analisis data yang digunakan yaitu reduksi data yang berarti berarti merangkum, memilih halhal yang pokok, memfokuskan pada hal-hal yang penting, dicari tema dan polanya, display (penyajian data), dan pengambilan keputusan atau proses verifikasi.

\section{Hasil dan Pembahasan}

Responden penelitian yaitu 2 orang mahasiswi yang bekerja menjadi pekerja seks komersial di daerah Jakarta, Kedua mahasiswi ini tinggal di rumah kosan di daerah Jakarta Timur. Perkenalan peneliti dengan responden dengan yaitu bermula saat peneli-ti kos di daerah Jakarta Timur. Saat itu peneliti me-ngenal salah satu responden dengan inisial Rani dan responden tersebut sering mengungkapkan masalah yang dialaminya kepada peneliti. Setelah beberapa lama berteman, Rani mengaku bahwa dirinya menyambi menjadi PSK dan sejak saat itu Rani bebe-rapa kali mengungkapkan kegelisahan dan kecemasannya karena pekerjaan sambilannya tersebut. Dengan "menerima informasi" tersebut, kemudian peneliti pun meminta izin kepadanya untuk dijadikan sebagai subyek penelitian skripsi, Rani bersedia dengan syarat identitasnya disamarkan, dan peneliti pun menyetujuinya. Kemudian peneliti meminta responden untuk mengajak satu temannya lain- 
nya sebagai subyek penelitian skripsi, Rani setuju dan mengajak salah satu temannya lagi, yang berinisial Mawar dan kebetulan satu kosan juga dengan responden dan peneliti. Selanjutnya, berikut ini keterangan lebih lengkap mengenai identitas responden ditunjukkan pada tabel 2.

Tabel 2. Profil Responden

\begin{tabular}{|c|c|c|c|c|c|}
\hline Nama & Jenis Kelamin & Anak Ke & Usia & Pendidikan & Agama \\
\hline Rani & Perempuan & 3 & 22 & $\begin{array}{c}\text { semester 8, } \\
\text { UNJ }\end{array}$ & Islam \\
\hline Mawar & Perempuan & 2 & 21 & $\begin{array}{c}\text { semester 8, } \\
\text { STIE Jakarta }\end{array}$ & Islam \\
\hline
\end{tabular}

Berdasarkan hasil pembahasan diketahui untuk strategi coping pada subjek Rani, strategi problem focused coping Rani cenderung untuk melakukan Confrontative Coping (menghadapi), Rani memang cenderung untuk tidak bertindak langsung ketika dia menghadapi hal yang tidak menyenangkan baik di tempat kerja maupun di lingkungan kosannya, Rani cenderung untuk tidak menghiraukannya. Tetapi ketika Rani tidak mood melayani tamunya, Rani akan bertindak langsung untuk tidak melanjutkan menemani tamunya. Ketika menghadapi tantangan Rani dapat menghadapi tantangan tersebut dengan cukup baik, di antaranya Rani tahu bagaimana caranya untuk menghadapi perasaannya sendiri ketika sedang sedih dan Rani juga memiliki motivasi diri yang baik untuk dirinya sendiri, Rani lebih senang untuk menceritakan masalah yang dia hadapi kepada sahabatnya dibandingkan memendamnya sendiri sehingga dengan cara seperti itu Rani bisa mendapatkan motivasi dari sahabatnya. Rani juga memiliki seeking social support (dukungan sosial) yang baik.

Rani sering meminta dukungan sosial baik saran maupun semangat dari keluarga dan temannya. Ketika meminta saran dari keluarga, Rani tidak menjelaskan permasalahan yang dialaminya secara detail, terutama yang berkaitan dengan pekerjaannya sebagai pekerja seks komersial, Rani hanya menceritakan garis besarnya, dengan adanya saran dan semangat dari teman dan keluarga, Rani merasa dapat lebih tenang. Rani memiliki Planful Problem Solving (perencanaan) yang cukup baik, Rani dapat melihat pilihan dengan cukup objektif dan dapat mempertimbangkan beberapa kemungkinan sebelum dia bertindak. Dia mengetahui apa dampaknya jika terus menarik diri dari lingkungan sosial, se- hingga dia pun mencoba untuk bergabung dengan teman-temannya walaupun tetap dibatasi, selain itu Rani juga tidak mebiarkan dirinya untuk larut dalam kesedihan karena dia tahu bahwa dengan terus-terusan bersedih dia akan tertekan dan akhirnya mencari pelarian dengan merokok atau minum-minuman keras. Rani juga mengetahui resiko fisik yang dihadapi ketika dia memasuki dunia pelacuran sehingga dia mencegah resiko dengan cara mewajibkan tamunya untuk memakai kondom jika berhubungan seks dengannya.

Pada strategi emotion focused coping, Rani kurang memiliki self control yang baik, Rani cenderung pasrah ketika teman-temannya membicarakan hal buruk tentang dirinya dan Rani malah melarikan ke aktifitas negatif ketika dia tidak dapat melupakan kesedihannya dengan cara merokok dan minumminum. Akan tetapi Rani dapat memperlihatkan emosinya ketika ada temannya yang menanyakan pekerjaannya sebagai PSK. Rani sering melakukan distancing atau mengambil jarak dari peristiwa yang menimbulkan stres. Rani akan memilih jalan-jalan dengan temannya untuk melupakan masalahnya akan tetapi Rani tidak akan menghindari temannya jika berselisih paham dengan temannya tersebut, Rani hanya menunjukkan ekspresi kekesalannya. Rani memiliki positive reappraisal yang baik, Rani dapat melihat sisi positif dari situasi stres yang dia alami, yaitu untuk tidak menemani tamu yang sebelumnya tidak dia kenal untuk mencegah kekerasan fisik dari tamunya, Rani juga dapat mengerjakan tugas kuliahnya apabila dikucilkan oleh teman-temannya dan ketika sedang bersedih, Rani dapat merenungkan kesalahan-kesalahannya.

Selain itu Rani juga memahami peranan dirinya ketika dia mengahadapi masalah, di antaranya Rani mengetahui tindakan apa yang harus dia lakukan agar bisa terlibat aktif dengan lingkungannya yaitu dengan cara ikut berkumpul dengan temantemannya. Rani memiliki accepting responsibility (tanggung jawab) yang cenderung kurang, ketika ada masalah Rani cenderung untuk mengalihkannya pada aktifitas merokok atau minum-minuman keras yang jelas merugikan dirinya sendiri. Rani tidak melakukan coping dengan cara Escape/menghindar, Rani tidak menarik diri dari lingkungan sosialnya dan Rani juga menceritakan masalahnya apa- 
bila dia sedang merasa tertekan.

Berdasarkan hasil wawancara, strategi problem focused coping Mawar menggunakan Confrontative Coping (menghadapi) dengan cukup baik, Mawar akan bertindak langsung jika dia mengalami keadaan yang tidak menyenangkan, misalnya jika Mawar mendapatkan kekerasan fisik dari pelanggannya Mawar akan langsung memarahi tamunya, begitupun ketika dia sedang tidak mood untuk melayani tamunya, Mawar akan langsung meninggalkannya, akan tetapi Mawar cenderung tidak bertindak ketika ada temannya yang berbicara buruk tentangnya, Mawar memilih untuk tidak memiliki konflik dengan temannya.

Mawar juga merasa tertantang saat mendapatkan perlakuan yang tidak me- nyenangkan dari tamunya bahwa dia harus menghadapinya seorang diri dan saat Mawar berada dalam perasaan yang tidak menyenangkan Mawar tertantang untuk tetap bisa terlihat senang di depan tamunya. Mawar juga memiliki motivasi diri yang baik, Mawar akan memotivasi dirinya dengan cara shoping atau berbelanja ketika dia mendapatkan masalah di tempat kerjanya, selain itu jika Mawar merasa bersalah karena pekerjaannya sebagai ayam kampus maka Mawar memotivasi dirinya bahwa tidak selamanya Mawar akan menjadi pekerja seks komersial. Mawar memiliki Seeking Social Support (dukungan sosial) yang kurang.

Mawar cukup sering meminta saran serta dukungan dari teman dekatnya. Dengan meminta saran dan dukungan dari temannya Mawar merasa dapat memperbaiki perasaannya. Akan tetapi Mawar jarang meminta dukungan dan saran dari keluarganya karena Mawar tidak ingin orang tuanya khawatir apalagi mengetahui pekerjaan Mawar yang sebenarnya. Mawar hanya sesekali meminta dukungan keluarganya jika merasa tubuhnya kurang sehat. Mawar memiliki Planful Problem Solving (perencanaan) yang baik, Mawar dapat melihat pilihan secara objektif, Mawar mengetahui ada pekerjaan lain selain PSK yang dapat menghasilkan uang, Mawar juga memiliki pilihan berteman dengan teman lainnya apabila teman-teman di sekitar tempat tinggalnya menjauhinya. Akan tetapi jika dirinya sedang bersedih memikirkan masalahnya Mawar cenderung untuk membiarkan perasaannya berlarut-larut dalam kesedihan. Mawar juga dapat mempertimbangkan kemungkinan sebelum dia bertindak, Mawar mengetahui resiko apa yang akan dia hadapi ketika dia memasuki dunia pelacuran sehingga dia meminimalisir resikonya, Mawar juga mengetahui dampaknya jika dia terus menarik diri dari lingkungan sosial dan juga dampak jika Mawar terus menerus tertekan karena pekerjaannya sebagai PSK.

Pada strategi emotion focused coping, Mawar cenderung kurang memiliki self control (pengendalian diri), Mawar cenderung bertindak pasrah setelah berusaha, ketika temannya ada yang membicarakan hal buruk tentangnya. Mawar cenderung cuek, juga ketika dia tidak bisa melupakan kesedihannya, Mawar justru memilih obat tidur untuk melupakan kesedihannya.

Ketika menghadapi masalah Mawar justru cenderung memperlihatkan emosinya, Mawar akan langsung memarahi tamunya yang bertindak kasar kepadanya dan menyerang balik temannya jika menanyakan pekerjaan sambilannya sebagai PSK. Mawar juga melakukan distancing/mengambil jarak dari peristiwa yang menimbulkan stres, Mawar akan tidur atau shoping untuk melupakan masalahnya dan Mawar juga akan menghindari terlebih dahulu terhadap temannya yang memiliki masalah dengannya.

Mawar melakukan Positive Reappraisal dengan baik, dia dapat melihat sisi positif dari situasi stres yang dialaminya. Mawar akan lebih waspada untuk menemani tamunya yang belum dia kenal untuk menghindari kekerasan fisik dari tamunya, Mawar juga merasa lebih dekat dengan Tuhan jika dalam keadaan bersedih, sebab dia akan berdoa kepada Tuhannya dan Mawar akan punya waktu untuk merencanakan bisnisnya apabila dia dijauhi teman-temannya, akan tetapi Mawar juga kurang dapat memahami peran dirinya. Mawar tidak berusaha untuk terlibat aktif dengan lingkungan di sekitarnya. Mawar cukup memiliki accepting responsibility atau tanggung jawab, ketika ada masalah Mawar cenderung untuk tidak mengalihkannya pada aktifitas merokok atau minum-minuman keras yang jelas merugikan dirinya sendiri. Mawar cenderung melakukan coping Escape/menghindar, Mawar menarik diri dari lingkungan sosialnya dan Mawar juga tidak menceritakan masalahnya apabila dia sedang merasa tertekan kecuali apabila Mawar merasa tidak sanggup lagi untuk menahannya. 


\section{Kesimpulan dan Saran}

\section{Kesimpulan}

Hasil penelitian menunjukkan bahwa subjek Mawar mengalami stresor lebih banyak dari subjek Rani. Untuk strategi coping pada subjek Rani menggunakan problem focused coping yaitu dengan menceritakan masalah yang dihadapinya kepada teman dekatnya dan emotion focused coping yaitu dengan cara merokok untuk mengatasi stresnya, sedangkan subjek Mawar lebih cenderung menggunakan emotion focused coping saja yaitu dengan memendam kecemasannya dan berpura-pura tidak terjadi apa-apa, menarik diri dari lingkungan masyarakat dan juga sering meminum obat tidur agar bisa melupakan masalahnya.

\section{Saran}

Saran yang dapat diberikan berdasarkan hasil penelitian ini bagi pihak-pihak terkait yaitu

\section{Saran untuk Mahasiswa}

Adanya pilihan dalam kehidupan kita, tergantung kita akan mengambil pilihan yang benar atau yang salah. Selain itu, mahasiswa dapat mencari inspirasi untuk menghadapi masalahnya.

\section{Saran untuk Konselor}

Sebagai konselor agar dapat melatih keterampilan untuk mengarahkan coping stres yang dihadapi kliennya tersebut berfokus pada masalah (Problem Focused Coping).

\section{Saran untuk Orang Tua}

Orang tua dapat mengarahkan anaknya untuk mengambil strategi coping yang positif saat anaknya sedang dalam keadaan tertekan atau stres.

\section{Daftar Pustaka}

Agoes Dariyo. 2003. Psikologi Perkembangan Dewasa Muda. Jakarta: PT Gramedia Widiasarana.

Dede Mulyani. 2003. Metodologi Penelitian Kualitatif . Bandung: PT Remaja Rosdakarya.

Isti Oktavianti. 2007. Stres dan Coping Stres pada Remaja PSK. Jakarta: tidak diterbitkan.

J.W. Santrock. 2007. Remaja. Jakarta: Gelora Aksara Pratama.

Kartono Kartini. 2007. Patologi Sosial Jilid I. Jakarta: PT. Raja Brafindo Persada.

Koentjoro. 1999. Melacur sebagai kewajiban kerja: Sebuah ketidakadilan gender sistematik. Jurnal Perempuan, No 11.

Lazarus \& Folkman. 1984. Stres apprasial \& coping. New York: Springe Publishing.

Leo Goldberger and Shlomo Brenitz (ed). 1982. Handbook of Stress, Theoritical and Clinical Aspects. New York: The Free Press.

Ritma Reina. 2008. Gambaran Stres dan Coping Stres pada Anak Perempuan yang Menjadi Korban Prostitusi. Jurnal Skripsi Universitas Atmajaya. Jakarta: tidak diterbitkan.

Sugiyono. 2012. Metode Penelitian Pendidikan. Bandung: Alfabeta. 